DOI: $10.2478 /$ aussoc-2020-0008

\title{
The Digital Space Dimension in Education. A Review on a Pilot Research
}

\author{
Dóra SZABÓ \\ University of Debrecen, Hungary \\ szabo.dora@arts.unideb.hu \\ Erzsébet DANI \\ University of Debrecen, Hungary \\ dani.erzsebet@inf.unideb.hu
}

\begin{abstract}
Following a short review on the importance and challenges of digital education, we review some of the findings of a study which we conducted on the basis of an online survey among students of the teachertraining programme at the University of Debrecen (for the purposes of a pilot project) in 2019. The 75 respondents were between 18 and 23 years of age and mostly students of humanities and natural sciences. The survey is obviously not representative, its function being to serve as a ground of a pilot survey to further our work and to extend it to other universities. Among others, the results show that $62.7 \%$ of the students learnt the use of digital tools by self-improvement; the majority of future teachers (85.3\%) are willing and motivated to use ICT tools in the context of education. The question regarding the importance of reading in a digital world showed that almost each of the respondents considered reading to remain an important activity. In order to make reading attractive, respondents emphasized the need to renew compulsory literature and to use digital tools for reading.
\end{abstract}

Keywords: digital education, ICT tools, teacher training

\section{Introduction}

In current days, the devices of the digital world can be found in nearly all fields of life. The effects of these gadgets have changed our communication, information processing, administration, shopping and other habits, not to mention the ways in which we search for information. Therefore, it can be stated that gadgets interweave with our daily lives. Education cannot be excluded from this paradigm shift. There is an extensive amount of literature, both international and national, that highlights this phenomenon and its effects. 
In our world, education requires the role of a modern teacher, which implies the use of digital tools. However, turning to digital education brings a lot of problems to teachers (McGarr-McDonagh 2019, Rokones-Krumsvik 2014). There is not enough effort put in the development of digital competence, and digital education is not upto-date, so that students did not receive the proper knowledge in their education.

Digital competence is one of the eight key competences and refers to the confident and critical usage of the full range of digital technologies for information, communication, and basic problem solving in all aspects of life (Digital Agenda Scoreboard 2015). Digital literacy comprises a set of basic skills, which include the use and production of digital media, information processing and retrieval, participation in social networks for the creation and sharing of knowledge, and a wide range of professional computing skills. ICT covers any product that will store, retrieve, manipulate, transmit, or receive information electronically in a digital form (UNESCO 2018).

Digital competences differ across generations, i.e. across baby boomers (born between 1944 and 1964), Gen X (born between 1965 and 1979), Gen Y (born between 1980 and 1994), and Gen Z (born between 1995 and 2015) (Dani 2013).

In this study, we will focus on a narrower aspect of the digital world - namely, the digital space used by the teachers of the future, the development of digital competence, the composition of the current teacher-training curriculum -, with particular emphasis on information and communications technology (hereafter ICT) and on the question of how digital dimension affects reading as an activity. Our research is based on a pilot study in which we asked students of the teacher-training programme at the University of Debrecen to answer the following questions:

1. Does the current teacher-training programme prepare the teachers to the correct, appropriate, and conscious use of ICT tools? Also, how the development of digital competence is present in the curriculum?

2. What opportunities do digital tools give to teachers in order to bring younger generations closer to reading?

The goal of the research was to get a broader picture on the digital competence of the teachers who take part in higher education. During the research, I contacted students through electronic questionnaires. The respondents take part in the teacher training of the University of Debrecen. I collected my data for 2 months, and then I evaluated the results, which were compared with the results of other countries' research studies and which showed that respondents' digital competence was not enhanced by either public or higher education. 


\section{Digital Competence}

We consider competence to be a complex system of knowledge, skills, abilities, personality traits, and attitudes that enables its owner to act efficiently in different situations, i.e. to solve complex tasks. Nowadays, digital presence does not depend on ICT tools but rather on knowledge, skills, and attitude. Thus, it is not the existence or lack of digital tools that stands in the middle of our questionnaire (though it was asked from students in the pilot study) but the ability and intention to use these digital tools. In other words, it is important for a future teacher to use these tools during the teaching process. According to the European framework, digital competence can be divided into 5 fields: information, communication, content creation, security, and problem solving ( $A$ digitális kompetencia értelmezésének európai keretrendszere 2013: 3-11).

The Hungarian education policy attributes a special significance to digital competence - thanks to which it is present within the 8 key competences marked by the Hungarian National Core Curriculum (hereafter NCC). According to NCC, digital competence means the use of information technologies and the content that can be accessed through them, which relies on skills and activities while also presupposes high-level logical abilities. All of this requires critical thinking, information management skills, and algorithmic thinking. In the case of digital competence, knowledge of the Internet and electronic communication are to be highlighted as well as the rules of information handling, Internet usage, critical thinking, and creativity (Nemzeti Alaptanterv 2012: 10654-10655). Thus, in public education, all students need these skills, abilities, knowledge, and attitude, and they also have to improve these. Let us suppose that the teachers who teach them possess these skills, abilities, knowledge, and attitude and make use of them in daily educational practice.

In connection with digital competence, we must mention the role of the generation: in the current public education, the digital immigrant teacher is confronted with the digital native students, and this situation is not symmetric at all. This situation is also true for the young teachers - however, as they are part of generations $\mathrm{Y} / \mathrm{Z}$, they have the competence of a digital native person - because the development of digital tools has accelerated to such an extent that the constant change can only be followed through the constant development of competence.

The fact that the European Commission displayed the Digital Agenda of Europe (DAE) in May 2010 is also strongly connected to this. This action plan and strategy is intended to boost the development of the EU's economy and spread the achievements of the digital age at all levels of society between 2010 and 2020. It aims to create sustainable economic and social benefits through a unified digital market based on high-speed and super-fast Internet and collaborative applications (Digital Agenda of Europe 2011). With all these objectives in mind, the DAE report of 2015 is particularly surprising, according to which $40 \%$ of Europe's population does not 
have an adequate level of digital competence and, within that, 22\% (a surprisingly high number) do not use the Internet regularly. It is somewhat reassuring that in the yearly reports these percentages do change year after year, but they still have not reached the expectations (Digital Agenda 2015).

One of the main pillars of DAE is "the spread of digital literacy, abilities, and equal opportunities". The plan also provides help to local initiatives to connect to significant European resources, thus making the question of digital literacy an important imperative in every country. At the national level, this is only possible if governments have a digital renewal strategy and they implement that immediately. If digital abilities do not spread fast enough in Europe, then the other important goals of the DAE will not be reached either.

The Digital Agenda specifies the conceptual frame of digital competence as follows (Borbély 2013: 120):

1. Access to ICT:

- computers,

- Internet,

- smart phones,

- tablets.

2. Personal competences, skills for basic usage/handling:

- basic proficiency of computer usage,

- basic proficiency of Internet usage.

3. Active applications relevant for life situations:

- work/profession,

- learning (LLL),

- communication,

- social connection,

- free time,

- social network.

4. Personal attitudes:

- critical, conscious usage;

- responsible usage;

- legal and ethical viewpoints;

- confident usage;

- creative usage.

If we project the competency framework to higher education, it could be concluded that the current curriculum model of the teacher-training programme supports the first environmental factors - namely: in higher education, access to ICT is provided as the computer infrastructure and Internet access are adequate at the University's faculties, institutions, departments, and libraries. Personal competencies and skills for basic usage are also supported in higher education: without these, the students cannot handle the university email system, NEPTUN, and e-learning interfaces. The 
active applications relevant for life situations are also permanent factors in the field of higher education. However, in the case of personal attitudes, there is still work to be done: they do not put enough emphasis on improving these attitudes in the curriculum model.

Due to the increasingly fast-paced technology, $5 \%$ of existing professions are replaced every 5 years, and professions that can be pursued/practised without the knowledge of info-communicational technologies are decreasing in every 2 years with another $5 \%$. In 10 years' time, the acquired professional knowledge becomes obsolete. The rapid development of information technology (IT) radically transforms our entire society, and only those can prevail in this changing world who can understand these changes. Two factors can be considered as the key to success - digital literacy and the conscious usage of info-communication techniques (Zóka 2011).

In the light of this, it is especially important to project these facts and the changes generated by them to the profession of teachers - namely: the teacher of the future cannot be successful without the ability of digital literacy and conscious use of ICT tools. This does not mean that young teachers can only be "good and successful" educators and instructors if they have these abilities but that they consciously and adequately place their "digital pencil case" in their teaching methodology.

From the perspective of our topic (with special regard to the fact that in the current dual teacher-training system students choose the library science teacher programme in increasing numbers), I find the representative survey of EFOP application frameworks conducted in 2018 - that measured 21 $1^{\text {st }}$-century Hungarian librarians' competencies with a focus on digital competence - very important. That survey measured the digital competence of the respondents in basic, intermediate, and advanced level across 5 dimensions of the framework of DIGCOMP: information, communication, content creation, security, and problem solving.

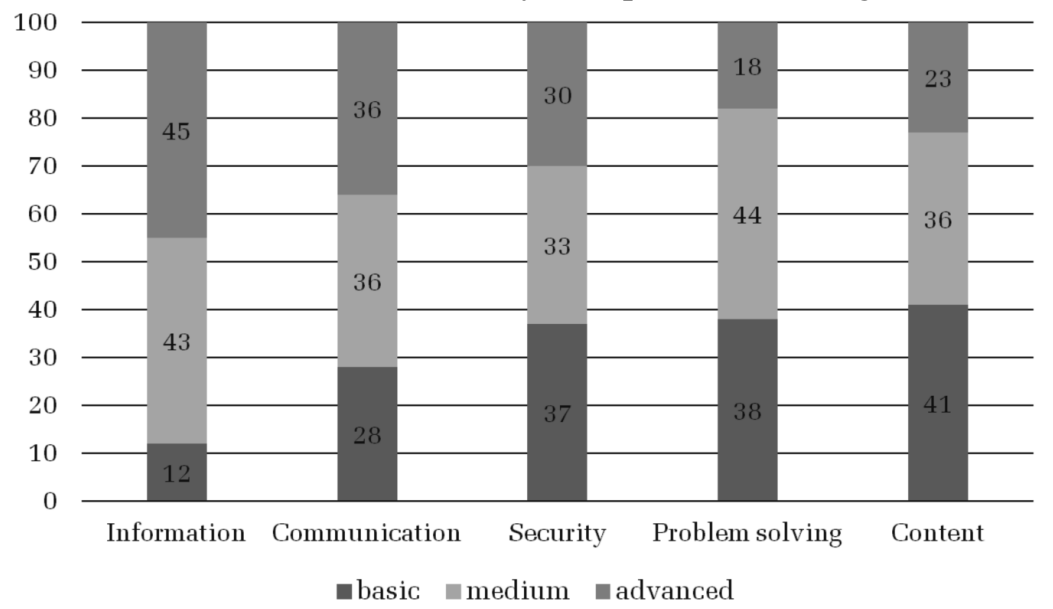

Figure 1. Librarians' digital competences (\%) 
As Figure 1 shows, questions were asked to measure the components defined in the framework of digital competence, the result of which shows the definitive knowledge of the information component which, compared to the other levels and competence components, shows the highest ratio. Problem solving yielded the lowest percentage on the advanced level, which could be caused by the inadequate use and lack of technology and innovation. The content component reached the highest rate on the basic level, which is possible because it has recently become one of the most basic digital competencies in librarianship. The improvement of this field will be important in the following years to help our librarians advance from the basic level. Security is not the main profile of a librarian, wherefore it can be said that the knowledge of the respondents in this competence is dispersed (Borbély 2018). The data of this survey are relevant for our study because the Library Science Teacher Programme (together with the IT librarian programme) is run in Hungarian higher education exclusively by the Faculty of Informatics at the University of Debrecen. This means that the curriculum model of the subject is strongly consistent with the Faculty's field of study: the IT block receives a special importance, so that the students can acquire information processing, descriptive markup language, database management, networking, multimedia, and webpage editing skills, and this definitely means an advantage for them.

The digital competence framework specifically made for teachers has already been released. The DigCompEdu specifies six areas of development (professional environment, developing and shaping digital resources, managing the use of digital tools, evaluation, improving the independent capacity of students, improving the digital competence of students) and 22 elements of competence (DigCompEdu 2017). We cannot forget the transversal function of digital competence from the point of view of education: it provides help to improve other competencies, for example, improving skills such as mother tongue, foreign languages, mathematical and other science skills, also in the strengthening of communication.

\section{Digital Literacy}

Digital (computer) literacy consists in the improvement of those abilities that allow the user to take advantage of the possibilities provided by their computers, e.g. word processor, table manager, and the knowledge of other user-based software, applications. The knowledge of the Internet is also strongly connected to this, just as the importance of multimedia tools. Besides this, we interpret traditional knowledge as an umbrella term for the synthesis of computer and information literacy. In an info-communicational society, the knowledge and acquisition of the so-called digital literacy is indispensable. Without that, we cannot keep up with the constant improvements. Its broad definition connects different concepts of literacy marked by collocations/phrases. 
The components of digital literacy are: literary literacy (reading), documentation literacy (use of forms), numerical literacy (creating spreadsheets), language literacy (use of foreign language), and computer and Internet literacy (how to use ICT (Zóka 2011)). Computer-related skills and abilities are important components of this knowledge, not to mention the effective use of information and communications technology (ICT). The latter is specifically prominent because digital literacy often receives a narrower interpretation in Hungary, which only wants to be aware of the use of ICT. In current teacher-training programmes, the use of ICT tools formally appears in each university, some universities having separate IT blocks. However, in many places, the appearance of electronic learning environments in the educational materials is only theoretical, which can be so because of the lack of infrastructure or teaching resources.

\section{ICT}

The use of IT tools at a social level is very important, as we have already indicated above. They offer many opportunities; thus, they have a bigger role not only in the field of economics but in education as well. ICTs are a combination of tools, technologies, organizational activities, and innovative processes that make communication, information processing, information flow, storing of information, and encryption easier and more effective (Molnár-Kis-Tóth 2015).

Some of the tools and equipment created during the course of scientific and technological development (e.g. printing press, projector, computer, etc.) were introduced into education with some delay following their invention. To apply ICT in education, proper device partners are required: more computer rooms, digital devices, and maintenance. ICT education implies to offer proper background to schools, so that teachers learn how to use these tools; they also have to be motivated and provided with continuous training. But not only schools, teachers also have to be prepared for the innovation, that is, the proper use of ICT tools (Taddeo et al. 2016).

\section{Generational Issues in the Digital World}

Many (typically in social studies and humanities) studies and scientific articles address the different aspects of generational change. According to these, the names of these generations are also colourful: veteran, baby-boomer, Generation X, Y, Z, Alfa, millennials, Net Generation, Internet generation, Bit Generation, etc. In this study, we will use the commonly accepted Generation X, Y, and Z expressions, 
or Bit Generation, ${ }^{1}$ which is a collective expression for generations Y and Z. Our approach is motivated by the Hungarian professional literature, which prefers these denominations and separations of the generations, on the one hand, while the digital native and digital migrant approach also use these expressions, which makes our choice plausible, on the other hand.

As we noted above, the following question often comes up in public education: Who has the advantage in the information society, the digital immigrant teacher or the digital native student? This approach will slowly expire because students in higher education, that is, prospective teachers will already be digital natives themselves. Thus, in theory, the tension in the digital dimension is slowly fading away. However, ICT-related problems continue to exist as far as digital literacy, which is essential for education, is not clearly equal with the naturalness of using e-tools. Another aspect of high importance to us is the aspect of teaching students to be literates: how do prospective teachers imagine educating their future students to become ICT literate? In generational connotation, teachers are part of Generation Y or Z, while students already belong to Generation Alpha.

The digital literacy characteristics for particular generations are summarized in Table 1 below (Dani 2012).

Table 1. The digital literacy of generations

\begin{tabular}{|c|c|c|c|c|}
\hline & Baby boomer & Generation X & Generation Y & Generation Z \\
\hline & \multicolumn{2}{|c|}{ Digital migrant } & \multicolumn{2}{|c|}{ Digital native } \\
\hline & & & \multicolumn{2}{|c|}{ Bit Generation } \\
\hline $\begin{array}{l}\text { The need } \\
\text { to access } \\
\text { information } \\
\text { quickly }\end{array}$ & average & accelerated & accelerated & immediate access \\
\hline Being up-to-date & very important & important & very important & $\begin{array}{c}\text { of central } \\
\text { importance }\end{array}$ \\
\hline $\begin{array}{l}\text { The competency } \\
\text { of information }\end{array}$ & very important & important & important & disinterested \\
\hline Further education & it does not matter & less important & important & important \\
\hline Life-long learning & not important & less important & important & very important \\
\hline $\begin{array}{l}\text { "Big picture" } \\
\text { (literacy, lexical } \\
\text { knowledge, wide } \\
\text { horizons, open- } \\
\text { mindedness, } \\
\text { refined mind) }\end{array}$ & very important & important & not important & does not matter \\
\hline $\begin{array}{l}\text { linear reading or } \\
\text { hypertext }\end{array}$ & linear reading & $\begin{array}{l}\text { linear reading and } \\
\text { hypertext }\end{array}$ & $\begin{array}{l}\text { less linear } \\
\text { reading, more } \\
\text { hypertext }\end{array}$ & mostly hypertext \\
\hline $\begin{array}{l}\text { active or passive } \\
\text { reading }\end{array}$ & passive & passive & active & active \\
\hline
\end{tabular}

1 The expression of Bit Generation was first used by Erzsébet Dani (2013) in her article titled E-létezés és hiperfigyelem. 


\begin{tabular}{lcccc}
\hline & Baby boomer & Generation X & Generation Y & Generation Z \\
\hline & \multicolumn{2}{c}{ Digital migrant } & \multicolumn{2}{c}{ Digital native } \\
\hline Belles-lettres & high percentage & high percentage & decreasing & fading \\
\hline $\begin{array}{l}\text { Professional } \\
\text { literature }\end{array}$ & high percentage & high percentage & high percentage & $\begin{array}{c}\text { medium } \\
\text { percentage }\end{array}$ \\
\hline Use of e-books & not typical & not really typical & typical & strongly typical \\
\hline $\begin{array}{lcccc}\text { Critical attitude } \\
\text { Use of digital } \\
\text { media }\end{array}$ & strongly advanced & advanced & average & undeveloped \\
& contacting others & entertainment & $\begin{array}{c}\text { learning, } \\
\text { entertainment, } \\
\text { communication }\end{array}$ & $\begin{array}{c}\text { communication, } \\
\text { entertainment, } \\
\text { learning }\end{array}$ \\
\hline
\end{tabular}

Source: Dani (2012)

The table speaks for itself (however, it does not contain reading data), ${ }^{2}$ and in the context of our survey it is thought-provoking, just like the following fact: after finishing school, the still reading generations' intention of reading has plummeted. We can rightly ask the question: how can teachers motivate students to read if they are not frequent readers themselves? We plan to have a large-scale national research in the future, in which we will try to address this question as well, and then reflect on the results.

\section{The Middle Ground}

In the context of our topic, we define the use of ICT tools in teacher-training programmes and the courses of the curriculum models that focus on digital competence, as the middle ground. The basic professional modules ensure the acquisition of expertise. At present, there is no such independent module in the teacher-training programme. The basic professional modules provide the acquisition of professional skills. The pedagogical-psychological module and/or professional methodology could be the most suitable choice to develop digital competences and to master the use of ICT tools at a high level. The former includes the practical lesson titled ICT in Education. This is the only class that contributes to the digital competencies of a teacher while also dealing with digital devices (mostly with interactive whiteboards).

The professional modules (as indicated above) do not contain classes that would deal with these. Occasionally, professional methodology deals with the digital toolkit for a few hours, but this is not a common practice. We need to highlight the teacherlibrarian training that - because of the already mentioned reasons - emphasizes IT-related subjects (at the IT Faculty, informatics module with 24 credits) - not specifically for education technology purposes, but nevertheless they contribute to the improvement of (the above mentioned) components of digital competencies.

2 More detail on this in the study of Dani (2012). 
In the course of our research, we made a survey to contact current students of the teacher-training programme at the University of Debrecen (for the purposes of a pilot project). The 13-question survey (for primer information acquisition) was sent out to the students attending different years of college with different majors as subject pairs, via the Internet. All responses were evaluable. The 75 respondents were between 18 and 23 years of age and mostly students of humanities and natural sciences. The questions were of various types: selective closed, partially, and fully open questions. The survey is obviously not representative, its function being to serve as a ground of a pilot survey to further our work and to extend it to other universities.

In one of the questions, we were curious about the way students learned the use of the given/listed digital devices. The answer was not surprising: $62.7 \%$ learnt by self-improvement. Our data show also that the majority of future teachers $(85.3 \%)$ are willing and motivated to use ICT tools in the context of education (Figure 2).

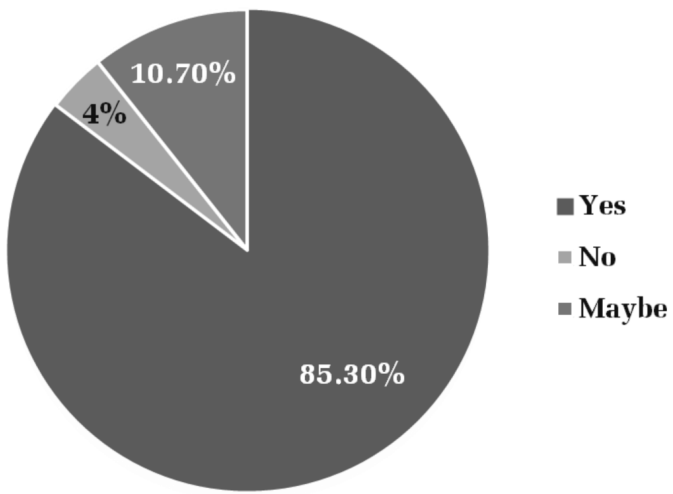

Figure 2. Willingness for the use of digital materials in education among future teachers $(N=75)$

Looking at the future, this is a very good starting point as all we need is an infrastructure in public education and creativity to make classes more colourful with digital devices. A large percentage of current teachers are not adequately familiar with these techniques, and they are only starting to familiarize themselves with them. In many cases, students can handle a given digital device better than the teacher.

Our results show that $76 \%$ of the respondents can use the interactive whiteboard, which is a very good rate considering the distribution of respondents based on their college years and that the subject of ICT in education is only taught during the fourth semester.

Future teachers would use projectors, interactive whiteboards, and Internet during classes. E-book and the overhead projector received the least amount of votes. The reason behind this could be that not a lot of schools have e-book readers, and, even if they do, they are available only in a small amount, so that students use 
them in groups and for group projects. Thus, Hungarian public education does not have the adequate infrastructure yet. Also, the projector has replaced the overhead projector. However, the overhead projector is still used by many teachers for certain task types and demonstrations.

In an open-ended question, we asked the respondents whether they use ICT tools in class with pleasure/willingly? Among others, they gave the following answers:

Yes, because it makes the class more colourful and smoother. The student can remember better if I demonstrate the given material.

No. They are surrounded by digital devices all day, and in classes these [instruments] do not grab their attention anymore. It depends on the teacher whether they can take advantage of the possibilities given by ICT tools. Students perceive that by using ICT they are not actually studying.

Maybe. Once during a survey, I asked the students whether a good teacher uses a lot of ICT tools or not. Half of the class answered that it is good to have these gadgets in class; however, classes can be just as good without them. However, I think they [students] like using them.

The majority of the answers show that in the opinion of future teachers the students have been born into a digital world, and new technologies make students become more motivated; ICT tools are interesting and attract attention, so that future teachers feel the need to integrate them in teaching. Thus, it seems that, indeed, the competencies of the current as well as future teachers have changed during the years (Zóka 2018).

The answers for the open question starting with "digital devices in the process of learning..." were mostly positive; they can be seen summarized below:

They can be useful if, e.g., in the absence of a library, we can read through electronic databases or collect professional literature. It can be a starting point because of the easier, faster, and more effective search. However, digital devices can distract the attention from the task.

The students we asked see different opportunities in digital devices. We received very imaginative and creative answers as well. Overall, they share the view that the use of visual devices is a great help in raising and maintaining attention and that they help the process of learning.

We can give creative tasks to the students. There are several opportunities for digital devices to improve the skills of students, especially in the case of language teaching. 
Personally, I would replace the books with tablets and e-books. It would be cheaper for the country and for the families as well. Books can be uploaded and we can forget the "I left it at home" excuse. Not to mention that while the student is in public education these tools should be replaced once or twice because of depreciation. In this way, there would be no need to spend billions a year on printing textbooks that students would barely open.

What I see is that we have not been taught how to use them, and the majority of current teachers cannot use them either because we receive theory-based education and training, and not practical skills. This is reflected at places where it is taught to teachers. However, the situation is much better now than it used to be, but we still must catch up.

Following the questions on ICT technologies, I proceeded with offering questions about reading and about the topic of how to teach people to become readers. Almost $100 \%$ of the respondents find this activity very important. According to my fellow students, the main avenues for educating readers are the renewal of compulsory literature and experimental education. The Project Gutenberg (i.e. a library of over 60,000 free e-books, being the oldest digital library in the world) received the least amount of votes, but it might be because students were not aware of it in spite of the fact that the Project Gutenberg can be used in literature classes (Gonda-Molnár 2019).

Among others, the following excellent ideas were given to motivate reading:

I would give them texts on topics that interest them. I think this is the first step in making them love reading. Their tasks would be to do different projects that cannot be done without reading. I would not give them Mór Jókai but, for example, Laura Leiner.

In primary school, I would not force them to read relatively difficult pieces of literature, like A köszívú ember fiai, but youth novels like Harry Potter. In this way, when they go to high school, they would be filled with experiences and a desire to read which would help them to read more, to understand, and enjoy more difficult works.

My last question was about linking ICT tools and reading: how they would solve the cooperation of these two VMIs. The following illustrative answers were given:

I would consult with my colleagues who teach Hungarian about what kind of reading they are currently doing that could be integrated into the IT class. Those who have not read it yet, they might get a feel for it. Furthermore, 
I would also explain the wide range of opportunities they have to read without carrying a book. (Even if that's not the best way to read.)

Reading has to be a positive experience, and we do not necessarily need ICT tools for that to happen.

I would not represent a primary standpoint. I still believe in paper-based reading as that is the true form of reading. Reading an article on the Internet is different from reading it on paper. However, readings on the Internet can be accessed faster and on any topic that I want. The search is faster, but I also read a lot of other things I do not want to.

At the intersection of the two question blocks, we can draw the following conclusion: future teachers find the use of ICT tools highly important. In their judgment, neither public education nor higher education provides the basic IT and digital competence foundations that would prepare them for the activities they consider important. And what is surprising is that a digital native university student (who would gladly use ICT tools at classes) handles the question of reading as a priority, stating that educating younger generations to become readers is an excessively important task. However, in achieving this, digital devices only mean an initial help: the true, in-depth reading and understanding (for now) can only be imagined within the Gutenberg galaxy.

\section{Instead of Conclusions: Teacher-Training Programme in the $21^{\text {st }}$ Century}

For a few years now, the Hungarian teacher-training programme has been dressed in a new-old robe; from split training to full-time training. The undivided teachertraining programme with two majors, which was introduced in 2013, lasts $4+1$ and $5+1$ years, in which the new +1 year is a novelty compared to the pre-Bologna system. The students spend one academic year after the theoretical-practical phase as an independent, coherent individual training phase on school grounds. This period is really about practice: young teacher candidates teach classes and engage in the teaching process in a school environment and therefore gain experiences that they can use in the future. In this period, university students are in constant connection with their professors and can ask for help and guidance from them. In the so-called "follower" methodical course, they can work together with their active methodology teachers from their major and minor subjects.

2019 is the year when the students who started their education in this system will graduate. The new system (in an almost natural way) carries all the "childhood 
diseases" because they do not yet have any experience in this field. These anomalies appeared during the systemic operation, which makes the work of education organization and education harder. The students who participate in the 1.0 version also played an experimental role, but they also helped to bring the problems of this system to the surface and demanded solutions. From these, the following question arises: what is the quality of education? It is not our job to answer this question, and we do not want to, either. However, it is an important moment in our field of research because we are looking for the answer to the following question: Does current higher education equip prospective teachers with the highest levels of digital competence to send them to teach an age-group whose members are no longer first-generation digital natives? Based on my personal experience as someone who participates in a full-time teacher-training programme, I can confirm that our insight into the digital world is inadequate during our training. As I mentioned earlier, according to the curriculum, a single subject addresses this topic; it is called ICT in Education, in the course of which we master the use of smart/digital boards, for which higher education institutions should provide adequate infrastructure. In our opinion, it would be a great improvement in the future if students were acquainted with the digital possibilities of the given science within the framework of professional methodology. This has already appeared in other countries, for example, in Germany.

Our study concentrated on current teacher-training programmes and (also) on the digital competence of teachers. Our aim was to measure the level of digital competence of future teachers and to elucidate what they think about whether digital devices should appear in education and what the pros and cons of this opportunity are for the future. Nowadays, we can hear a lot about this topic and what trends are emerging in education, to which the new National Core Curriculum will also contribute.

As the survey proves, a lot of question surfaces about the system of teacher training and also about digital competence. This pilot study opened further research directions as well. One direction would be to examine the components of digital literacy individually. Besides that, a larger survey would be necessary that would extend the research on a national level.

\section{Acknowledgment}

This work was supported by the construction EFOP-3.6.3-VEKOP-16-2017-00002. The project was supported by the European Union, co-financed by the European Social Fund. 


\section{References}

Borbély, Mária Eszenyiné. 2013. Digitális írástudás, digitális kompetenciák a statisztikai adatok tükrében. Tudományos és Múszaki Tájékoztatás 60(3): 120127.

2018. A végzettség és a könyvtárosok digitális kompetenciaszintje közötti összefüggések összehasonlító elemzése. Tudományos és Müszaki Tájékoztatás 65(5): 287-306.

Dani, Erzsébet Bujdosóné. 2012. Neumann kontra Gutenberg-galaxis?: különös tekintettel a generációs olvasási szokásokra. Könyv és Nevelés 4(14): 48-59. 2013. E-létezés és "hiperfigyelem”. Könyv és Nevelés 4: 36-45.

Ferrare, Anusca. 2013. A digitális kompetencia értelmezésének európai keretrendszere. (https://www.deaweb.hu/images/bongeszde/digcomp_teljes_ hun_151231.pdf).

Galántai, Zoltán. 2018. Oktatás: problémák és technológiák. Iskolakultúra 28(3-4): $64-69$.

Gonda, Zsuzsa, Molnár, Tamás Gábor. 2019. Irodalomértés és kreatív szövegfeldolgozás a digitalis magyarórán. Iskolakultúra 29(4-5): 33-49.

McGarr, Oliver, McDonagh, Adrian. 2019. Digital Competence in Teacher Education, Output 1 of the Erasmus+ funded Developing Student Teachers' Digital Competence (DICTE).

(https://www.researchgate.net/publication/331487411_Digital_Competence_in_ Teacher_Education).

Molnár, Tünde Lengyelné, Kis-Tóth, Lajos. 2018. IKT innováció.

(http://okt.ektf.hu/data/szlahorek/file/kezek/05_ikt_02_27/221ikt_fogalma. html).

Redecker, Christine, Punie, Yves. 2017. DigCompEdu. The European Framework for the Digital Competence of Educators. EU SCIENCE HUB

(https://ec.europa.eu/jrc/en/publication/eur-scientific-and-technical-researchreports/european-framework-digital-competence-educators-digcompedu).

Rokones, Fredric Mork, Krumsvik, Rune Johan. 2014. Development of Student Teachers' Digital Competence in Teacher Education - A Literature Review. Nordic Journal of Digital Literacy 9(4): 250-280.

Taddeo, Gabriella, Cigognini, M. Elisabetta, Parigi, Laura, Blamirer, Roger. 2016. Certification of Teachers' Digital Competence. Current Approaches and Future Opportunities. MENTEP Deliverable 6.1

(http://mentep.eun.org/documents/2390578/2452293/MENTEP_D6+1.pdf/ e9982840-f226-4b68-bebd-4fefeb67004e).

UNESCO. 2018. UNESCO ICT Competency Framework for Teachers. (https:// unesdoc.unesco.org/ark:/48223/pf0000265721). 
Zóka, Tünde Klenovitsné. 2011. Digitális nemzedék: megváltozott pedagógus kompetenciák.

(http://janus.ttk.pte.hu/tamop/tananyagok/digitalis_nemzedek/digitlis_ kompetencia.html).

*** 2015. Digital Scoreboard Reports. (https://ec.europa.eu/digital-single-market/ en/download-scoreboard-reports).

*** 2016. Digital Scoreboard Reports. (https://ec.europa.eu/digital-single-market/ en/download-scoreboard-reports).

*** 2017. Digital Scoreboard Reports. (https://ec.europa.eu/digital-single-market/ en/download-scoreboard-reports).

*** 2010. Európai Digitális Menetrend. (http://infoter.eu/alapdokumentumok/ europai_digitalis_menetrend).

*** 2012. Nemzeti Alaptanterv. (http://pszheves.hu/wp-content/uploads/2013/08/ nat_20121.pdf). 